\title{
GENESIS 50:15-21 AND ITS CHALLENGES TO RECONCILIATION PROCESS IN AFRICA
}

\author{
Emmanuel O Nwaoru \\ Catholic Institute of West Africa \\ Port Harcourt, Nigeria
}

\begin{abstract}
In the face of seemingly irreconcilable conflicts the world over, especially in some African countries, this article sets out to establish through a close reading of Gen 50:15-21 that permanent reconciliation between conflicting parties is achievable, as it was between Joseph and his brothers. It delineates from context a wide range of processes and effective strategies that lead to reconciliation, namely inspirational mediation, good timing for open and face-to-face dialogue, capacity to address contentious issues properly and conclusively, without mitigating the gravity of crime and its natural consequences, the magnanimity of the victim to let go, the courage of the offender to accept guilt, and a good theological motif. On the contrary, it discovers that lack of concrete and visible windfall of reconciliation can hinder achieving full settlement.
\end{abstract}

Key Words: Genesis, Brother, Reconciliation, Guilt, Bond

\section{Introduction}

Reconciliation does not just ensue; it involves a process, a process which in the case of a conflict may require chains of actions and reactions from the 'offender' (perpetrator), the 'offended' (victim), and the larger society. Our text, Gen 50:15-21, narrates the process leading to the reconciliation between the sons of Jacob in Egypt, specifically between Joseph and his brothers. Attention is drawn to this narrative because it contains certain factors which make full reconciliation possible. They include recognition of the origin of conflict, acceptance and confession of guilt, plea for forgiveness, and willingness on the part of the victim to forgive and even to ensure the wellbeing of the one time offender.

This article intends to examine the text to ascertain how these factors help to construct a paradigmatic process of reconciliation, a process that leads to ultimate settlement. It will do so by critically looking at the historical background and context of the text, its structure and form. The interpretation of the text will focus on what constitutes offence in the context, the approach to reconciliation and how the narrator perceives the offender and the victim. All this points to why the essay supposes that Gen 50:15-21 has great relevance to reconciliation process in Africa.

\section{Historical Background and Context of Genesis 50:15-21}

Genesis 50:15-21, a text that is rightly recognized as 'a self-contained scene' (Westermann 1986:204), is bounded remotely by Jacob's last words (blessing) to his sons (49:1-28a) and immediately by the death of Jacob (49:28b-50:14) and Joseph (50:22-26) respectively. Two antithetical but complementary attitudes mark off the unit, namely the anxiety of Joseph's brothers (v. 15) and Joseph's reassuring and comforting words to his brothers (v. 21b). The latter is antidotal to the former. However, the text has to be located and understood in its 
wider context, precisely within the larger section of Joseph Narrative (Gen 37-50). It is an episode situated in a family circle, in which the protagonists are identified as brothers (vv. $15,17 \mathrm{a}, 18$ ) and reference is made to 'their father' (cf. v. 15; also v. 16). The term 'brother' (' $\bar{a} h$ ) must be conceived here in its very strict sense as connoting blood relationship rather than a wider kinship tie (cf. Gen $37 ; 42$ ). ${ }^{1}$ Such a relationship presupposes a strong family tie where members experience fraternal solidarity and security. In fact, it will be a tragedy, if any of these is lacking. As Exodus 32:29 indicates, it is only loyalty to God that can take precedence over this natural bond of kinship.

Unfortunately, it is not fraternal bond that gives rise to Gen 50:15-21 in the first instance. The passage has its proper background in the alienation, hatred and treachery that Joseph experienced at the hands of his brothers (Gen 37; especially, vv. 4, 5, 8; cf. Gen 27:41-42). Hence the two underlying factors in the text - the brothers' apprehension for their lives and survival under Joseph's authority in Egypt after their father's death (Gen $50: 15,16)$ and the bitter mutual remembrance of the brothers' hatred and ill-treatment of Joseph (vv. 17, 20). The first is rooted in the second, having once experienced imprisonment in Egypt from Joseph (Gen 42:17). Nevertheless, it is the deep bond of family relationship that turns the cycle of hatred to the process of reconciliation narrated in the passage (vv. 16,17), facilitated by the lingering memory of the words of Jacob, their father, even after his death.

\section{The Text and its Structure}

The text of Gen 50:15-21 is not a very complicated one to comprehend. But the divergent readings of the opening word of v. 16 between the Hebrew text (MT) and the Septuagint (LXX) play no small role in determining the structure of the process of reconciliation. While the MT has wayșawwî (they 'ordered, ${ }^{2}$ left instructions, commissioned, sent message'), the LXX read paregénonto (they drew near, approached). ${ }^{3}$ The MT reading suggests that Joseph's brothers sent an emissary to Joseph to communicate to him their father's will, ${ }^{4}$ the LXX, on the contrary, narrates that it is Joseph's brothers who went direct to Joseph to remind him of the same. Both renderings are adopted by various translators. ${ }^{5}$ The MT reading suggests two important movements or stages in the process of reconciliation. First is the employment of an emissary to plead on behalf of the offenders (vv. 16-17) and, secondly, the face to face dialogue between the brothers that later followed (vv. 18-21).

That another stage in the process of reconciliation begins in v. 18 , outside that of the emissary, is clearly indicated by the verb of motion $h l k$ which introduces the verse. Other indicators include the adverbial particle gam (also) which suggests an additional but independent action of the brothers and the interjection particle hinneh (with the pronominal

In fact, C Westermann (1987:322) has pointed out that from the very beginning the Joseph story, as a whole, involves three parties: father, brothers, and a single brother, Joseph.

2 C Westermann (1986:376) considers a possible ellipsis here, leaving us with the rendition, "They ordered someone to inform Joseph," corresponding to "they sent Joseph a message."

3 Some scholars have made attempts to explain the variant readings through graphic confusion. But the letters of MT wayșawwî are hardly to be confused with the LXX probable Hebrew equivalent wayyigg ${ }^{e} \hat{s} \hat{u}$ as O Eißfeldt suggests in the BHS.

4 Cf. Esth 3:12; 8:9; also Exod 6:13; 25:22; Lev 27:34; Deut 1:3; Jer 27:4; Esth 4:10; BDB, 846.

5 For instance, ASV, NIV, NJB, RSV, TNK, etc., follow the MT: "They sent a message to Joseph," while NAB, NRSV, etc., the LXX: "They approached Joseph." Strikingly, the NRSV discarded MT of the RSV to adopt the LXX. 
suffix of the brothers) that leaves no one in doubt that Joseph's brothers and not the emissary are now the ones pleading their cause before Joseph. The verse reads: "His brothers also came, fell down before him, and said, 'We are here as your servants."' This structure contrasts with the one that emerges from the LXX reading, "They (Joseph's brothers?) approached Joseph, saying ..." (vv. 16-17). The LXX creates the impression that from the onset there is a single movement, involving the brothers pleading their cause in a face-to-face dialogue with Joseph. Giving the gravity of the thorny issues involved, which were well articulated in the words of their father (vv. 16b-17a; cf. v. 15), this may be unlikely. However, the impression is corrected in v. 18 where the LXX first narrates that Joseph's brothers went (elthóntes) to Joseph.

The MT reading in its present form presents a model uniquely known to the biblical and ancient world, including Africa. The preliminary use of intermediary, sending messages or writing letters, ${ }^{6}$ in handling grave matters is customary (Nwaoru 2002:28), be the issues marriage negotiations (Gen 24:53-56; 2 Sam 3:14), reconciliation moves/conflict resolutions (Gen 32:4-6 [Eng 3-5]; cf. vv. 14-21 [Eng 13-20]), apostasy (Exod 32:31-32; Num $14: 17-19)$, etc. It is understandable that Joseph's brothers must have tried to avoid direct discussion or confrontation with their brother Joseph because they were not sure how he would react in the first instance. Hence the need for an emissary. From the MT the structure of the passage can be sketched as follows:
A. V. 15 Preamble: The brothers' apprehension over their ill-treatment of Joseph
B. Vv. 16-17 Emissary pleads on behalf of Joseph's brothers in Jacob's own words
C. Vv. 18-21 face to face dialogue between the brothers and Joseph
a. v. 18 Joseph's brothers begin to plead their own cause
b. v. 19 Joseph reassures his brothers
$\mathrm{a}^{1}$. v. 20 Joseph gives basis for forgiveness and reconciliation
$\mathrm{b}^{1}$. v. 21 Joseph's further reassurance

\section{The Text and its Language}

A close reading of Gen 50:15-21 reveals that the narrative begins with a contrary-to-fact supposition ${ }^{7}$ of Joseph's brothers based on the fear that Joseph would revenge against them after their father's death. This is evident in the use of the preposition particle $l \hat{u}$ in $\mathrm{v} .15$. The apprehension gives rise to the use of different forms of speech in the narrative to allay the fears and pave way for a lasting reconciliation among brothers. First, the motivation for reconciliation is parallel to that which comes from the admonition/ teaching of a wise father, typical of the Wisdom corpus. The function of the adverbial particle $w^{e c}$ attāh in v. $17 \mathrm{~b}$ is unmistakable in the genre (cf. Prov 5:7; 7:24; 8:32; cf. 3:21; 28:13; also Deut 4:1). Interestingly, the words of Jacob in v. 17 are given as an earnest plea, cast in a formulaic language of prayer as is evident in the double use of the pre-active particle $n \bar{a}$,' "I pray". In the second phase of the reconciliation process (vv. 18-21), the dialogical section, Joseph's response is framed in the assurance formula 'al-tîrā' $\hat{u}$ "fear not!" "Do not be afraid!" (vv. 19, 21; cf. Gen 43:23; also 45:5) and punctuated by the rhetorical question, "Am I in the

6 For instances in which such letters are used for purposes other than reconciliation and conflict resolutions, see 2 Sam 11:14, 15; $1 \mathrm{Kgs} 21: 9 ; 2 \mathrm{Kgs} \mathrm{10:1,6.}$

7 Such a proposition is "not capable of fulfilment in the present or future" and therefore not real. Cf. GKC $\S 159$ 1; Lambdin 1971:§196. 
place of God?" (v. 19). It is interesting to observe that Jacob poses a similar question to Rachel, Joseph's mother in Gen 30:2, which as Hamilton (1995:705) rightly points out is in context of provocation. The same is also true of the king of Israel in reaction to the letter of the king of Syria (2 Kgs 5:7).

Here the context is definitively different; Joseph has earlier given his assuring and encouraging words to calm down his brothers' fears. The question gives a new dimension to the understanding of the true source of all forgiveness. God alone can forgive; and he alone can impose retribution, if he so desires (Deut 32:35; cf. 32:43; Ps 94:1; Rom 12:19; Heb 10:30). Having stated this, let us now examine further the roles which the structure and the forms observed in the text played in the process of reconciliation between Joseph and his brothers.

\section{Nature of Offence}

There seems to be a disagreement between Jacob and his sons on what actually constitutes the offence against Joseph. In the brothers' view they did $r \bar{a}^{c} \bar{a} h$ (evil) to Joseph (v. 15). Admittedly, Joseph himself accents to it (v. 20). But from the father's wise teaching the reader realises that the content is more diversified and elaborate. It consists of pešac (transgression), hatțta't (sin), and $r \bar{a}^{c} \bar{a} h$ (evil) (v. 17a). However, the messengers on their own plead for the transgression of Joseph's brothers (v. 17b). In other words, apart from the general ways Joseph's brothers hurt him by threatening and indeed seeking to destroy his life and change his good fortune for worse, as expressed in the word $r \bar{a}^{c} \bar{a} h,{ }^{8}$ they committed acts that not only breached the ties of blood kinship and violated their brother's human rights $\left(p e s ̌ a^{c}\right),{ }^{9}$ but also failed to hit the mark of keeping to the bonds of blood kinship (hatța $\left.{ }^{\prime} t\right)$. This is clearly brought out by the LXX rendering of hatța't as hamartia here. One has to notice that the use of the word pair peša $a^{c}$ and hatțát $\underline{t}$ is widely attested in the OT. In fact, Jacob has earlier used it in relation to Laban in Gen 31:36. It is also found in Exod 34:7; Job 13:23; Isa 1:28), in Jer 33:8 (in reversed order), Dan 9:24; in parallelism in Ps 32:1; Isa 43:27 (reversed); Mic 1:5; etc.

The wide semantic field of $r \bar{a}^{c} \bar{a} h$ indicates that 'evil deed' is the bottom line of the guilt of Joseph's brothers. It can be said to have absorbed the specific offences enlisted in Jacob's message both at their physical, psychological and moral levels and, therefore, clarify the seeming disagreement over the subject matter of guilt in the text. As Kellermann (2004:567) clearly puts it $r \bar{a}^{c} \bar{a} h$ in its broadest sense, "refers to everything that is bad." For Koch (1983:74) it "signifies the absorption and implementation of the results of human wickedness."

The great harm that has been done has set the scene for a social conflict among brothers and has far-reaching consequences (cf. Ezek 18:18; Isa 66:5). This explains the background of the use of words such as $s t^{10}$ (to bear grudge/animosity against), šû $\underline{b}$ (pay back), ${ }^{11}$

8 The LXX translates the word as poneros which embraces the idea of all that is evil, bad, wicked, sinful, etc., with its physical and psychological pains. Cf. Gen 44:4; Num 14:37; 1 Sam 25:21; Ps 34:12; Eccl 9:12; 11:2; Isa $3: 11$.

9 Cf. Gen 31:36; 1 Sam 24:11; 1 Sam 25:28; See also LXX adikia for peša ${ }^{c}$.

10 The root $s t m$ is more all-inclusive than $s^{\prime} n^{\prime}$ (to hate). It implies a deep seated grudge or animosity which leads to irrational persecution and harassment of one's fellow man (cf. Gen 49:23; also Amo 1:11; Ps 55:4 [Eng 3]) and can only emanate from an unforgiving heart such as that of Esau (Gen 27:41). Although the cause of apprehension here is known, Job gives the impression that the reason for the harassment arising from such animosity is unknown $(16: 9 ; 30: 21)$. The LXX renders it as mnēsikakeō "to remember past injuries" 
through which the brothers express their unfounded fears in v. 15 and $g m l$ (deal adequately with) in the same verse, to describe the nature of their deeds. The root $g m l$ is re-echoed in Jacob's message in v. 17a for the same purpose. It is the gravity of the offences that prompts the sending of message $(s w h)$ to Joseph (v. 16) with the twofold plea to Joseph to forgive his brothers (v. 17). It also provoked Joseph's tears in v. 17, the prostration of Joseph's brothers before him and their declaration of readiness to serve and submit to him in v. 18. Indeed, a situation that evokes such an apprehension and bitter memories demands nothing short of mutual reconciliation, which has already begun with confession/ repentance and forgiveness.

\section{Approach to Reconciliation in Gen 50:15-21}

Gen 50:15-21 does not speak directly of reconciliation, a word that is rarely used in the OT. ${ }^{12}$ But it speaks of "asking for forgiveness," and "granting pardon/forgiveness," that are basic and indispensable ingredients for reconciliation. Moreover, the structure of the passage, as we have earlier outlined, points to the fact that there is an inbuilt process that marks the text out as a comprehensive account of a well-designed move at re-establishing normal relationship among brothers; at bringing brothers back to a state of harmony and peace characteristic of blood kinship.

Here the process begins with the self-awareness $\left(r s h^{13}\right)$ of Joseph's brothers regarding their life-situation in Egypt - the reality of their father's death and the possible consequences it may have on them because of their past crimes against Joseph. The story of the Prodigal son in Luke 15:11-32 comes readily to mind. It is not our intention to probe the morality of a self-consciousness arising from fears of survival. What matters to us is that the process does not stop at self-awareness of Joseph's brothers; their self-awareness motivates them to rise to another level towards reconciling with Joseph, their brother.

Having realised the gravity of their offence and the possible danger of a face-to-face encounter with Joseph, they devised a plan. First, they have to formulate a passionate plea and feign it to be part of their father's last will - "Your father gave this command before he died. "Say to Joseph..." (vv. 16a-17a). The testament itself reads as follows: "Please, forgive the transgression of your brothers and their sin, because they did evil to you." The authenticity of this statement may be questioned for various reasons. For instance, Joseph's brothers are noted for telling lies to achieve their end, especially in relation to Joseph (cf. Gen 37:32-33, also vv. 20b, 31; 44:2) and perhaps in the manner of Jacob their father whose words may not always be trusted (cf. Gen 27:18-29, esp. vv. 19, 24; Hos 12:4 [Eng 3]; also v. 3[2]). Moreover, it is incomprehensible how Jacob would make such a plea through Joseph's brothers and not directly to Joseph who was physically present at his death (Gen 49:29-33; 50:1-2). Hamilton (1995:700) reckons the statement among three other statements attributed to individuals in 2 Sam 15:8; 2 Sam 16:3 when read together with 19:27; and $1 \mathrm{Kgs}$ 1:17 (cf. 1:30), which according to him are unverifiable. Whatever

"remember wrongs done one" (cf. Liddell-Scott 1968:\$26877). This indicates that the word retains all through the sense of hostile behaviour. Cf. K. Nielsen (2004:74).

11 The sense of the root in its hiphil form here is that of retribution and vengeance. It is to pay someone back for evil done as expressed clearly by the LXX antapodoma.

121 Sam 29:4 is the only instance the hithpael of the verb rșh (LXX diallássō) is used in that sense. Cf. Sir 22:22; 27:21; also RSV, NRSV, ASV, NKJ, KJV. However, some translators (NAB, NIV, NJB, NIB) render it as "to win back favour".

13 The Qal verb is used here in a metaphorical sense to denote a mental rather than physical act, namely "to perceive, feel, understand, learn, etc.," instead of its literal meaning "to see" with the eyes (cf. Gen 27:1). 
the case, the strategy has its useful purpose in the process of reconciliation, for the last words of a loving and wise father cannot be ignored (Prov 6:20; 7:1-3; 23:22).

Secondly, Joseph's brothers have to deliver the message through an emissary to Joseph. This provides the mediatorship needed to foster a peaceful atmosphere before their face-toface encounter with Joseph. In fact, the messengers' additional voices in the narrative reinforce the father's plea for forgiveness of Joseph's brothers - "Now, please, forgive the transgression of the servants of the God of your father," they said (v. 17b). This added intercession is very important. The mediating messengers employed the phrase, "the servants ${ }^{14}$ of the God of your father," commonly used in the Semitic world but only once here in the Hebrew Bible to appeal to what the brothers share in common - the covenant (Gen 26:24; Ps 105:6, 42; 1 Chr 16:13; Ezk 28:25; 37:25), the hopes of the patriarchs (Mal $3: 18$ ), and the worship of the God of their fathers (2 Kgs 9:7; 10:23; Ps 113:1; 134:1; 135:1; Isa 54:17; Dan 6:21). In fact, Ringgren (1999:394) identifies Gen 50:17 as one of those limited instances in which 'e $\underline{b} e \underline{d}$ denotes 'worshipper.' Ordinarily, the cliché 'the God of your father" evokes a spiritual bond (Gen 31:29; 43:23; 46;3; 49:25; Exod 3:9; 1 Chr 28:9), a bond that is thicker than blood relationship. It is within such an ambience that the messengers situate forgiveness. This makes reconciliation even more urgent and irresistible.

There is no doubt that the double request for forgiveness (v. 17a, b) made a deep impression on Joseph that he had to respond instantly by weeping (v. 17c). The implications of the verb 'to forgive' in its MT and LXX usage is outstanding. Ordinarily, the Hebrew $n s$ ' means 'to lift or raise up'; 'to bear, carry, support'; and 'to take, take away,' with each category expressing variant nuances. The LXX renders the Hebrew with aphiemi (to pardon, cancel) in v. 17a, but with déchomai ('to receive' = 'to take upon oneself, sustain, bear, endure ${ }^{15}$ ) in v. $17 \mathrm{~b}$ which brings out more clearly the solemn plea for pardon expressed by the MT construction $n s^{\prime}$ '...l . The focus here is on the sense of 'take away' in connection with sin, transgression, iniquity, thus denoting 'to pardon,' or 'to forgive.' Other verbs with synonymous sense include slh 'to forgive' and $k p r$ 'to atone'. ${ }^{16}$

Strictly speaking, the biblical tradition considers the action of taking away sin as belonging to God par excellence (Exod 32:32; 34:7; Num 14:18; Mic 7:18; cf. Josh 24:19; Ps $32: 1,5)$. It is therefore in this context that one can appreciate Joseph's hesitance to proclaim forgiveness and his rhetorical question, "Am I in the place of God?" (v. 19b). Nevertheless, emotional pleas have always been made to human beings as indicated in v. 17 to perform this divine act, namely to forgive the sin, transgression, and iniquity of their fellows. For instance, Pharaoh implores Moses (Exod 10:17), Saul pleads to Samuel (1 Sam 15:25) and Abigal to David (1 Sam 25:28). Like Jacob and the messengers in v. 17 Moses intercedes for Israel (Exod 32:32; Num 14:19). In this regard "sin can be forgiven and forgotten, because it is taken up and carried away" by the 'other.' The 'other' here implies both God and the neighbour (TWOT:1421).

The two key elements in the process of reconciliation have been met - forgiveness has been asked for and guilt has been admitted/ confessed - and the way is open for the crucial part of the process, the face-to-face encounter of Joseph with his brothers. But since the two

14 The LXX renders the MT ${ }^{c}$ ebed as therápōn, which has "attendant" among other meanings. This sheds some light on the understanding of the word in the context of divine worship, where worshippers see themselves as servants of God (Exod 4:10; Ps 19:12, 14; 109:28). In the temple of Asclepius, for instance, they were actually called attendants of God. See Burkert (1987:39; also 148 n.60); BDB, 714a); TWOT, 1553a.

15 Cf. Thayer's Greek Lexicon, 1271, 2.

16 H-J Fabry (1999:27-28) includes other verbs - nph (piel) "to declare innocent," $k s h$ (piel) "to cover" and ${ }^{c} b r$ (hiphil) used metaphorically "to let (sin, guilt) pass by. 
elements may require more than verbal expressions, Joseph's brothers follow the verbal up with symbolic gesture; they prostrated themselves before Joseph (v. 18). However, the LXX omits completely the act of prostration. Apart from this act signifying repentance (cf. Deut 9:18, 25; 2 Sam 19:19-20; Ezra 10:1), it also indicates that the brothers recognise Joseph's superior position (cf. Lev 26:7; 2 Sam 19:19) and are prepared to submit to his superior authority. The accompanying words, "We are here as your servants," the brothers' submission. It is important to observe that Joseph's dreams (Gen 37:7-11) meet partial fulfilment here as on other occasions (Gen 42:6; 44:14, 16).

On the part of Joseph, the offended, he does not say "I forgive you" directly. As is customary in ancient cultures he does so indirectly in his commitment to the cause of reconciliation. Besides Joseph's rhetorical question in respect to forgiveness of sin (v. 19b) he assumes "the place of God" in other areas on behalf of his brothers. He calms their fears (vv. 19a, 21a; cf. Gen 43:23), and promises to provide for them and their little ones (v. 21a) which are acts proper to YHWH. ${ }^{18}$ These too are elements that foster the bond of kinship and guarantee a lasting reconciliation. Above all, Joseph goes on to establish a theological foundation for reconciliation: "As for you, you meant evil against me; but God meant it for good, to bring it about that many people should be kept alive, as they are today" (v. 20). It is evident that without such an understanding about the offences individuals commit against their neighbours it will be difficult to grant forgiveness and pursue mutual reconciliation. It is such a theological motive that makes it possible for Joseph to comfort his brothers, speak kindly to them and thus achieve full reconciliation (v. 21b).

The process of reconciliation in Gen 50:15-21 can be distinguished from that of any other text of the OT. Its elements - dialogue, bowing down, giving/receiving gifts, embrace, falling about the neck, kissing, weeping, separation of the parties - are only found in part in three other passages dealing with reconciliation, namely Gen 13, esp. vv. 7-12 (Abram and Lot), Gen 33:1-17 (Esau and Jacob), and Gen 45:1-15 (Joseph and his brothers).

\section{The Protagonists}

Important to the reconciliation process in Gen 50:15-21 is the 'unveiling' of the characters of the two estranged parties, Joseph and his brothers, to the reader. The narrator presents the offenders, Joseph's brothers, in several of ways that sharply distinguish them from Joseph, the victim. In relation to Joseph they are identified in three ways, a) 'your brothers' (vv. 15, 17a, 18), b) "servants of the God of your father" (v. 17a), and c) 'your servants' (v. 18). According to the narrator, it is their father Jacob who calls them Joseph's brothers, while the messengers name them "servants of the God of your father". On their part, they identify themselves before Joseph as 'your servants' (cf. Gen 42:10, 11, 13; 44:7, 9, 16, 18). One has to recall that Jacob used similar self-designation (Gen 32:5, 19, 21[Eng. 4, 18, 20]) to pacify Esau whom he wronged in order to avert a possible act of revenge. Richard Schultz (1997:1188) goes further to draw good parallel between Jacob's dependence on Esau's favour for survival and Joseph's brothers reliance on Joseph's good will to obtain their grains, freedom, forgiveness, etc.

17 The LXX oikétēs for MT ${ }^{c}$ ebed indicates that although Joseph's brothers recognise themselves as servants, they want Joseph to consider them as house servants, i.e., members of his family (cf. Acts 10:7) and not as slaves (doûlos) engaged in servile or humble service in the house. The sense is also visible when the king's subject are said to be his servants (Gen 21:25; Exod 7:28).

18 See Ps 55:23(22) and Exod 16; 104:14-15, 27-28; 105:40-41; Hos 2:10-11(8-9); Isa 55:1-2 respectively. 
It is interesting to observe that the word 'brother' is never found on the lips of Joseph's brothers. For, throughout the Joseph narrative (Gen 37-50), they are shown not to behave as brothers to Joseph, either in words or in their deeds. Their sin hatțāt $\underline{t}$ is persistent, variant in nature, and deserves to be atoned for one day in YHWH's judgement. Koch (1980:312) distinguishes this intensive feminine form (with closed ending) from the simple form $h^{a} t \underline{a} \bar{a}$ 't $h$ that denotes individual deed. Nevertheless, Joseph's brothers are also depicted here in the text as those who are aware of their treacherous crimes against Joseph. Hence they identify their deeds as a sum-total of all that is evil kol-hara $\bar{a}^{c} \bar{a} h$ (v. 15). The definite article, $h a$, used with the fem. adj. absolute $r \bar{a}^{c} \bar{a} h$ (evil thing) testify to the veracity of their self-identification. The complication, however, is that although they had good sense of guilt, they never asked directly for forgiveness from Joseph. This probably explains why Joseph on his part does not say: "I forgive you". Nevertheless, they express their admission of guilt and their request for forgiveness symbolically, by prostrating themselves before Joseph (v. 19). ${ }^{19}$ The symbolic action of Joseph's brothers, which is a useful gesture of reconciliation, complements the verbal plea of Jacob and the messengers respectively.

In contrast to the image of his brothers, Joseph is presented as an all-round model of a vicarious sufferer, and an embodiment of the qualities that make for true reconciliation. He is unassuming about these qualities, and does not presume to cross boundary of his appropriate role in the process of reconciliation. For Joseph knows very well that forgiveness is first and foremost the gift of God.

To the chagrin of his brothers and the reader Joseph has a different attitude towards appreciating injuries inflicted on him. Rather than opt for revenge, as the brothers well expected (v. 15), Joseph is portrayed in all self-resignation and sobriety. He speaks openly and frankly to his brothers and discourages them from being remorseful by his encouraging and reassuring words - "Do not be afraid". Above all, Joseph is more willing to mitigate the consequences of the brothers' treacherous deeds against him by rather integrating them into a divine plan than to emphasise the punishment they would merit before YHWH, the God of vengeance. Joseph's image here could have later influenced some rabbinic teachings. Walter Grundmann (1964:17 n.19) cites two such sayings from rabbinic literature, namely "A man should always be in the habit of saying, "All that the Allmerciful does, He does for good"" (bBer. 60b), and the frequently used formula, "This or that happened unto me for good" (Str.-B., III, 255), which reflect Joseph's saying.

Perhaps the best image of Joseph in the narrative is that of a personality with human heart. This is demonstrated not only when he weeps over the brothers' misconception of the real demands of the bond of kinship (v. 18) but also in the manner of handling his brothers and their crimes against him. To those who perpetuate treachery and hurt, Joseph speaks tenderly and comforts them (v. 21; Isa 40:1-2; cf. Gen 34:2-3; Judg 19:3; Ruth 2:13; Hos 2:16[Eng 14]).

19 This form of obeisance is widely known in biblical tradition and other ancient cultures, including Africa. It is primarily a mark of respect in greetings (Gen 18:2; Exod 18:7); in paying homage (1 Sam 28:14); in acknowledging authority (Ruth 2:10; 2 Kgs 2:15); in imploring a favour (1 Sam 2:36); etc. It is a familiar feature of Jacob's family. As Terence E Fretheim (1997:43) rightly points out Jacob bows for Esau (Gen 33:3; cf. 27:29), Joseph bows before Jacob (48:12; cf. 37:10) but here refuses his brothers showing him such respect (contrast Gen 42:6; 43:26, 28). 


\section{Process of Reconciliation in Gen 50:15-21 and African Context}

Africa has been branded a continent in perpetual conflicts. It is not the intention of this essay to probe into the veracity or falsity of such claim. It suffices to admit that for long the continent has witnessed a number of protracted deadly conflicts, especially in the Great Lake region, in Somalia, Sudan and in some states of Nigeria. These conflicts could have been fully settled, if only appropriate processes were adopted by the different parties involved. Genesis 50:15-21 presents a paradigmatic process which when adopted could make full reconciliation possible, even on the continent. The validity of the process lies in the fact that it worked between Joseph and his brothers after earlier attempt at reconciliation (ch 45) failed. Certain factors made reconciliation possible in this second encounter of the brothers. For instance, the pardon said to be given to the offenders by the victim is not presumed, knowing that it requires reassurance and concrete gestures for the pardoned to be psychologically convinced that forgiveness is genuine. The frequent relapses to cycles of hostility and violence point to some extent to the inherent lack of mutual trust on the part of parties in conflict. To build this trust is one of the greatest challenges facing the peacebrokers of our time.

Another area of challenge is guaranteeing the proper disposition of perpetrators of evil towards reconciliation. It is not easy to achieve this. But as the narrative indicates, Joseph's brothers sued for reconciliation only when they realised after their father's death how precarious their lives and survival could be under Joseph's authority in Egypt. They also saw the need to address the contentious issues properly and conclusively without any attempt to mitigate the gravity of their offences and their natural consequences (v. 15). This serves as the way to purify the memory of the offender and to assure the healing purpose of reconciliation. ${ }^{20}$ For the process of reconciliation to begin at all, our text reveals the need for inspirational leadership of a father-figure. It comes to Joseph's brothers from the memoir of their father (vv. 16a-17b). Appealing to parental figure and memoir is widely used as relevant motif for initiating negotiations and peace movements in Africa. It also discourages any quick rush into establishing a direct contact between the conflicting parties at the first instance or even a cheap reconciliation. This is to forestall any escalation. Instead, mediators are to be engaged to serve as agents of reconciliation (v. 16-17). Traditional African society knows the strategy; some groups such as the Igbo of South-East Nigeria have often appealed to all loyalties, especially the agnates of one's father or/and mother to resolve conflicts (Uchendu 1965:67-68). It is also within the same context that appeal is made to blood relationship ('your brothers') and to spiritual bond in order to rekindle social and religious ties and mutual solidarity (v. 17a, b). For it is believed that no better person can mediate peace in conflict than the one who shares the bond of kinship, and that any peace mission imposed from 'outside' is bound to fail. This challenges African nations to engage more assiduously in mediating peace and in finding solution to the numerous problems in the continent, using appropriate cultural strategies.

Our text shows that good timing is necessary for fruitful dialogue between conflicting parties. It takes place after the preliminary stages of the process have been concluded. As the high point of the process the procedure of the dialogue is paramount. The narrator devoted four (18-21) out of the seven verses to it. The face-to-face dialogue opens with symbolic gestures of the offenders, Joseph's brothers, accompanied by words that express good sense of guilt and cooperation (v. 18), but which for Joseph were no conditionalities

20 Cf. the Lineamenta (2006) of the Second Special Assembly for Africa, the Church in Africa in Service to Reconciliation, Justice and Peace, n. 68. 
for mutual reconciliation. Not even their being short of directly asking for forgiveness could change Joseph's positive reaction to his brothers' gestures and words. He mitigates the force of the consequences of their guilt by dispelling their anxiety. In fact, Joseph is not only prepared to bear his brothers' guilt (v. 19), but also to excuse their evil machinations against him by integrating everything into the plan of God (v. 20). This is one unforgettable lesson of the narrative that must not be glossed over. Joseph does not insist on retribution, on allotting to his brothers what they exactly deserve based on the gravity of their offences. With him (retributive) justice fails to carry the legal meaning often attached to it, namely giving to each what is his or her due. This is because the law may not adequately redress the wickedness and the harm which the brothers did to him. The emphasis is that in pursuit of full reconciliation the conflicting parties, especially the victim, must at some point allow retributive justice to lose its legal force. The reason is aptly captured in an Igbo proverb, Iwe nwanne anaghi eru n'okpukpu - "the anger against one's kinsfolk does not get to the marrow".

To further reassure his brothers Joseph matches his words with actions. He promises them a welfare package (v. 21). Joseph's attitude here is unrivalled in the OT; it prefigures NT teachings on love, mercy, and forgiveness of one's enemy. ${ }^{21} \mathrm{He}$ realises, through the victim, that full reconciliation means nothing with an empty stomach, and when basic human needs are not addressed. Therefore, going beyond the rhetoric of reconciliatory statements to seeking in earnest the well-being of the adversary remains a key factor in achieving lasting peace in the conflicting areas in Africa.

\section{Conclusion}

Our close reading of Gen 50:15-21 has exposed the fact that lasting reconciliation among conflicting parties is not a mirage; it is achievable. At least our text has shown that it has functioned in the case of Joseph and his brothers. It has also indicated that more than anything else reconciliation requires proper approach, which includes among others, gaining the good disposition of the conflicting parties, especially that of the offender, having the appropriate inspiration for negotiations, and using the right agents of reconciliation. It demands perfect timing for open dialogue and a good theological basis. The fragile and volatile 'ceasefires' and short-lived reconciliations achieved at different times in conflict areas in the content are indicative of the need for a more comprehensive approach. Gen 50:15-21 poses the challenge and at the same time offers different communities and governments in Africa a blueprint for achieving lasting reconciliation.

\section{BIBLIOGRAPHY}

Brown, Francis, Driver, SR, Briggs, Charles A 1907. A Hebrew-Aramaic and English Lexicon of the Old Testament (BDB). London: Oxford University Press.

Burkert, Walter 1987. Ancient Mystery Cults. Cambridge, London: Harvard University Press.

Fabry, H-J 1999. “ "nāśs $\bar{a}$,, in G Johannes Botterweck, Helmer Ringgren, Henz-Josef Fabry, eds. Theological Dictionary of the Old Testament (TDOT) X. Grand Rapids: Wm B Eerdmans.

21 Matt 5:43-45; Luke 6:27, 35; Rom 12:17-21; 1 Thess 5:15; cf. Luke 23:34; Acts 7:60. 
Fretheim, Terence E 1997. “ $h w h$," in WA VanGemeren, et al (eds.) New International Dictionary of Old Testament Theology and Exegesis (NIDOTTE) 2. Carlisle: Paternoster Press.

Grundmann, Walter 1964 “agathos,” in Gerhard Kittel, Geoffrey W Bromiley, eds. Theological Dictionary of the New Testament (TDNT) 1. Grand Rapids: Wm B Eerdmans.

Hamilton, Victor P 1995. The Book of Genesis Chapters 18-50. [NICOT]; Grand Rapids: Wm B Eerdmans.

Harris, RL, Archer, GL, Waltke, BK 1992-2003. The Theological Wordbook of the Old Testament (TWOT), in: Bushell, MS, Tan MD. BibleWorks LLC 6.

Kellermann, D 2004. " $r \bar{a} c \bar{a} h$," in G Johannes Botterweck, Helmer Ringgren, Henz-Josef Fabry, (eds.). Theological Dictionary of the Old Testament XIII. Grand Rapids: Wm B Eerdmans.

Koch, Klaus 1980. "chātâa,", in G Johannes Botterweck, Helmer Ringgren, eds. Theological Dictionary of the Old Testament IV. Grand Rapids: Wm B Eerdmans, 1980.

Koch, Klaus 1983. The Prophets. I. Philadelphia: Fortress Press.

Lambdin, Thomas O 1971. Introduction to Biblical Hebrew. London: Darton, Longman \& Todd.

Liddell, HG, Scott, RA 1986. Greek-English Lexicon. Oxford.

Nielsen, K 2004. "śātāan,” in G Johannes Botterweck, Helmer Ringgren, Henz-Josef Fabry, eds. Theological Dictionary of the Old Testament XIV. Grand Rapids: Wm B Eerdmans.

Nwaoru, Emmanuel O 2002. "Old Testament Perspective on Bride -Price: Meaning for the African Church as Family," in: J-B Matand Bulembat, (ed.), The Church as Family and Biblical Perspectives. Kinshasa: Imprimerie Saint Paul.

Ringgren, H 1999. “c $\bar{a} \underline{b} a \underline{d}$," in: G Johannes Botterweck, Helmer Ringgren, Henz-Josef Fabry, eds. Theological Dictionary of the Old Testament X. Grand Rapids: Wm B Eerdmans.

Schultz, Richard 1997. "Servant, Slave," in WA van Gemeren, et al (eds.). New International Dictionary of Old Testament Theology and Exegesis 4. Carlisle: Paternoster Press.

Thayer, Joseph Henry 1992-2003. Thayer Greek-English Lexicon of the New Testament in: Bushell, MS, Tan MD. BibleWorks LLC 6.

Uchendu, Victor C 1965. The Igbo of Southeast Nigeria. New York: Holt, Rinehart and Winston.

Westermann, Claus 1986. Genesis 37-50: A Commentary. Minneapolis, Augsburg Publishing House.

Westermann, Claus 1987. Genesis Practical Commentary. Grand Rapids: Wm B Eerdmans. 